\title{
Awareness Level of Plant Health Engineering Practices among Vegetable Growers
}

\author{
P. Rajapandi ${ }^{1 *}$, L. Nirmala ${ }^{2}$ and K. Mahandra Kumar ${ }^{3}$ \\ Department of Agricultural Extension and Rural sociology, Agricultural College and \\ Research Institute, Madurai district, Tamil Nadu, India. \\ *Corresponding author
}

\section{Keywords}

Pesticide, Plant health Engineering, Vegetable crops, Sprayer, Pesticide application

Article Info

Accepted:

12 October 2020 Available Online: 10 November 2020

\section{A B S T R A C T}

The vegetable plays a vital role in the daily supplement of food. Frequency of the pesticide spray is higher in the vegetable crops. In order to optimize the use of pesticide and proper PPE usage Plant Health Engineering practices will help to overcome this. The present study was conducted in the Thiruparankundram and Alanganallur blocks of Madurai district of Tamil Nadu with 120 respondents. A well constructed Interview schedule was used to collect data. The findings reported that vegetable growers had medium level of awareness ( 70.8 per cent) about the plant health engineering practices. But most of the vegetable growers were not aware about the effect of pesticide on the field. Lack of awareness about the toxicity labels, measuring device for pesticide quantity, recommended chemical for pest and diseases in brinjal and tomato, nozzles and calibration of the sprayer should be well educated to the farmers through the KVKs , NGOs and Agricultural departments. It is well known that the year 2020 was proclaimed by the United Nations General Assembly as the International Year of Plant Health (IYPH). The year offers a once-in-a-lifetime opportunity to raise global awareness of how plant health security can help end hunger, alleviate poverty, protect the environment, and boost economic growth. Plant health is increasingly under threat. Climate change and human activities have altered ecosystems, reducing biodiversity and creating new niches where pests can thrive. At the same time, international travel and trade, which have tripled in volume in the last decade, can quickly spread pests and diseases around the world, causing great damage to native plants and the environment. It is much more cost-effective to protect plants from pests and diseases than to deal with full-blown plant health emergencies. To prevent the devastating effect of pests and diseases on agriculture, livelihoods and food security, prevention is crucial and all of us have a role to play.

\section{Introduction}

Hence it is essential to protect the plants from the pest and disease in effective way by optimizing the pesticide use.
About Two-thirds of total pesticides used in vegetables were dominated by the Insecticides. The maximum pesticide usage is in Chilli (5.13a.i $\mathrm{kg} / \mathrm{ha}$ ) followed by brinjal (4.60 a.i kg /ha), Cole crops (3.73 a.i kg /ha) and okra (2-3 a.i $\mathrm{kg} / \mathrm{ha})$. The pesticide 
application to brinjal crop was more than the crops like chillies, cauliflower and bhendi (Jeyanthi and Kombairaju, 2005). About 13 percent of the total pesticide consumption in the country is consumed by the fruits and vegetables with only a cropped area of 3 per cent (Nigam and Murthy, 2003).

\section{Materials and Methods}

The study area was Madurai district of Tamil Nadu, India. In this district Thiruparankundram and Alanganallur blocks were selected based on the higher area under vegetable cultivation. There were 120 respondents were selected for this study. Among them 60 tomato and 60 brinjal farmers were selected randomly in the study area.

\section{Results and Discussion}

Awareness level about plant health engineering practices (Table 1)

From the table it could be seen that Table 1 that majority (70.8 per cent) of the respondents had an medium level of awareness about the plant health engineering practices pursued by high level of awareness about the plant health engineering practices $(17.5 \%)$ and the rest 11.7 per cent of the respondents had low level of awareness about plant health engineering practices. Hence majority of the vegetable growers had medium level of awareness about the plant health engineering.

Awareness about plant protection measures (pest) in Brinjal and tomato (Table 2)

\section{Pest}

It is clearly evident from the table 2 that 93.33 per cent of vegetable growers were aware about the fruit and shoot borer in brinjal pursued by 78.33 per cent were aware about the whitefly and 66.66 percent of the respondents were aware about aphids in brinjal.

Regarding the symptoms 93.33 per cent of the respondents were aware about the symptoms caused by fruit and shoot borer followed by 71.66 per cent aware about symptoms caused by whitefly and 60 per cent were aware about the symptoms caused by aphids. 80 percent of the respondents were aware about the recommended chemicals (Profenphos40\%+ Cypermerthin 4\%) for fruit and shoot borer and all of the respondents were aware about the recommended quantity of chemicals also. With regard to whitefly only 33.33 per cent of the brinjal growers were aware about the recommended chemical (Malathion 50EC) and 45 per cent of the growers were aware about the recommended chemical (Dimethoate 30EC) and 94.44 per cent and 95.65 percent aware about the recommended quantity of chemical in whitefly and aphids.

Regarding the tomato pest, 90 percent of tomato growers were about the fruit and shoot borer followed by 71.66 per cent and 66.66 per cent of the farmers were aware about whitefly and aphids. 88.33 per cent were aware about the symptoms of fruit and shoot borer in tomato pursued by 65 per cent aware about the symptoms of whitefly.

Awareness about plant protection
measures (diseases) in Brinjal and tomato (Table 3)

\section{Diseases}

With regard to brinjal diseases 96.66 are well aware about the little leaf of brinjal followed by 81.66 well aware about the damping off, 83.33 aware about symptoms of alterneria leaf spot and 68.33 well known about root knot 
nematode. Regarding the recommended chemicals $46.66 \%$ adopted the recommended fungicide followed by only $35 \%$ were aware about the recommended chemical and $43.33 \%$ knows the recommended quantity of chemical. $31.66 \%, 16.66 \%$ and $21.66 \%$ are thorough about the recommended quantity of chemical of damping off (copper oxychloride at $2.5 \mathrm{~g} / \mathrm{l}$ ), alterneria leaf spot (mancozeb @ 2 $\mathrm{g} / \mathrm{l}$ ) and root knot nematode (carbofuran $3 \mathrm{G}$ (a) $10 \mathrm{~g} / \mathrm{m} 2$ ).

Regarding the tomato diseases, the tomato growers are well aware about the symptoms of early blight $(88.33 \%)$, damping off $(71.66 \%)$, fusarium wilt $(70 \%)$ and tomato leaf curl virus( $100 \%$ ) while $50 \%, 35 \%, 33.33$, and $45 \%$ were aware bout the recommended chemicals of early blight (Hexaconazole 5\% SC @ 1ml/1 or propiconazole 25\% EC @ 1 $\mathrm{ml} / \mathrm{l}$ at 30 and 50 days after planting), damping off (copper oxychloride at $2.5 \mathrm{~g} / \mathrm{l}$ ), fusarium wilt and tomato leaf curl virus (Dimethoate $30 \mathrm{EC} @ 1 \mathrm{ml} / \mathrm{l}$ or malathion 50 EC @ $1.5 \mathrm{ml} / 1$ or methyl demeton 25 EC @ $1.0 \mathrm{ml} / \mathrm{l})$.

\section{Awareness about the plant health engineering practices (Table 4)}

There were, 100 per cent of the respondents were found to be aware about the preparation of the spray fluid, quantity of water that should be mixed to prepare the spray fluid and pesticide mixture. It is also observed from the table that 39.16 per cent of the respondents understood the categorization of toxicity colour codes of scientific interpretation while 60.83 per cent of the respondents could not understood the toxicity colour codes. It is inferred that the majority of the respondents $(60.83 \%)$ were not aware about the toxicity of the labels like red (extremely toxic), green (slightly toxic), blue (moderately toxic) and yellow (highly toxic) are printed on the pesticide containers.
Calibration of the sprayer is the rate at which the pesticide is sprayed uniformly over the whole field area. It can be worked out theoretically and practically in the field by using the formula $F=S D A / 10000$. About 100 percent of the respondents were not aware about the calibration of the sprayer.

It is found that most of the respondents (80 $\%$ ) were not aware about the type of nozzles used in the sprayers since they were not aware about the type of nozzle name in the market. In the field scenario, most of them were using gaseous energy nozzles which is used in the motorized knapsack sprayer but they were not aware about it. About 20 per cent of the respondents were aware about the nozzles used in the hand held sprayers.

Droplet consideration is also important for spraying the pesticide. It is found that nearly 77.50 per cent of the respondents regulate the droplet size in knapsack sprayer by using the flow regulator knob while spraying according to their need and growth of the crop.

Swath width is the width of the field covered by a nozzle while spraying. Swath width is also determined by the pressure of the spray, wind velocity and crop growth. More the pressure and wind velocity greater the swath width of the nozzle. All of the respondents $(100 \%)$ were not aware about the swath width while spraying the pesticide in the field.

Awareness of spraying techniques of low volume, high volume and ultra volume is also a important vital factor for spraying the pesticides.

Most of the respondents $(82.50 \%)$ were not aware about the spraying techniques and only 16.66 per cent of the respondents were aware about the low volume spray fluid requirement i.e., 50-150 litres per hectare 
Table.1 Distribution of the respondents according to the overall awareness level of plant health engineering practices $(n=120)$

\begin{tabular}{|l|l|c|c|}
\hline S.No. & Category & Frequency & Percentage \\
\hline $\mathbf{1 .}$ & Low & 14 & 11.7 \\
\hline $\mathbf{2 .}$ & Medium & 85 & 70.8 \\
\hline $\mathbf{3 .}$ & High & 21 & 17.5 \\
\hline & TOTAL & $\mathbf{1 2 0}$ & $\mathbf{1 0 0}$ \\
\hline
\end{tabular}

Table.2 Distribution of the respondents according to the awareness of plant protection measures (Pest) in Brinjal and Tomato $(n=60)$

\begin{tabular}{|c|c|c|c|c|c|c|c|c|c|}
\hline \multirow[t]{2}{*}{ S.No. } & \multirow[t]{2}{*}{ Category } & \multicolumn{2}{|c|}{ Pest } & \multicolumn{2}{|c|}{ Symptoms } & \multicolumn{2}{|c|}{$\begin{array}{l}\text { Recommended } \\
\text { chemical }\end{array}$} & \multicolumn{2}{|c|}{$\begin{array}{l}\text { Quantity of } \\
\text { chemical }\end{array}$} \\
\hline & & No. & $\%$ & No. & $\%$ & No. & $\%$ & No. & $\%$ \\
\hline & Brinjal pest & & & & & & & & \\
\hline 1. & Fruit and shoot borer & 56 & 93.33 & 56 & 93.33 & 48 & 80 & 48 & 100 \\
\hline 2. & Whitefly & 47 & 78.33 & 43 & 71.66 & 20 & 33.33 & 17 & 94.44 \\
\hline 3. & Aphids & 40 & 66.66 & 36 & 60 & 27 & 45 & 22 & 95.65 \\
\hline & Tomato pest & & & & & & & & \\
\hline 1. & Fruit and shoot borer & 54 & 90 & 53 & 88.33 & 48 & 80 & 48 & 100 \\
\hline 2. & Whitefly & 43 & 71.66 & 39 & 65 & 20 & 33.33 & 17 & 94.44 \\
\hline 3. & Aphids & 40 & 66.66 & 34 & 56.66 & 27 & 45 & 22 & 95.65 \\
\hline
\end{tabular}

Table.3 Distribution of the respondents according to the awareness of plant protection measures (diseases) in Brinjal and Tomato $(n=60)$

\begin{tabular}{|c|c|c|c|c|c|c|c|}
\hline \multirow[t]{2}{*}{ S.No. } & \multirow[t]{2}{*}{ Category } & \multicolumn{2}{|c|}{ Symptoms } & \multicolumn{2}{|c|}{$\begin{array}{l}\text { Recommended } \\
\text { chemical }\end{array}$} & \multicolumn{2}{|c|}{$\begin{array}{l}\text { Quantity of } \\
\text { chemical }\end{array}$} \\
\hline & & No. & $\%$ & No. & $\%$ & No. & $\%$ \\
\hline & Brinjal diseases & & & & & & \\
\hline 1. & Little leaf of brinjal & 58 & 96.66 & 28 & 46.66 & 26 & 43.33 \\
\hline 2. & Damping off & 49 & 81.66 & 21 & 35 & 19 & 31.66 \\
\hline 3. & Alternaria leaf spot & 50 & 83.33 & 19 & 31.66 & 10 & 16.66 \\
\hline \multirow[t]{2}{*}{4.} & Root knot nematode & 41 & 68.33 & 21 & 35 & 13 & 21.66 \\
\hline & Tomato diseases & & & & & & \\
\hline 1. & Early blight & 53 & 88.33 & 30 & 50 & 16 & 59.25 \\
\hline 2. & Damping off & 43 & 71.66 & 21 & 35 & 19 & 31.66 \\
\hline 3. & Fusarium wilt & 42 & 70 & 20 & 33.33 & 11 & 55 \\
\hline 4. & Tomato leaf curl virus & 60 & 100 & 27 & 45 & 10 & 52.63 \\
\hline
\end{tabular}


Table.4 Distribution of the respondents according to the awareness level of plant health engineering practices among vegetable growers $(n=120)$

\begin{tabular}{|c|c|c|c|c|c|}
\hline \multirow[t]{3}{*}{ S.No. } & \multirow[t]{3}{*}{ Questions } & \multicolumn{4}{|c|}{ Aware } \\
\hline & & \multicolumn{2}{|c|}{ Yes } & \multicolumn{2}{|c|}{ No } \\
\hline & & No. & $\%$ & No. & $\%$ \\
\hline \multicolumn{6}{|c|}{ Preparation of spray fluid } \\
\hline 1. & Are you aware of the preparation of spray fluid? & 120 & 100 & - & - \\
\hline 2. & $\begin{array}{l}\text { Are you aware of the quantity of water must be used to prepare the } \\
\text { spray fluid? }\end{array}$ & 120 & 100 & - & - \\
\hline 3. & Are you aware of the pesticide mixture? & 120 & 100 & - & - \\
\hline \multicolumn{6}{|c|}{ Toxicity colour code } \\
\hline 4. & Are you aware of Toxicity colour codes? & 47 & 39.16 & 73 & 60.83 \\
\hline \multicolumn{6}{|c|}{ Calibration and nozzles } \\
\hline 5. & Are you aware of calibration of sprayer? & - & - & 120 & 100 \\
\hline 6. & Are you aware about type of nozzles used in sprayer? & 24 & 20 & 96 & 80 \\
\hline 7. & $\begin{array}{l}\text { Do you regulate droplet size while spraying the pesticide in mist } \\
\text { blower? }\end{array}$ & 93 & 77.5 & 27 & 22.5 \\
\hline 8. & $\begin{array}{l}\text { Are you aware of the spraying techniques } \\
\text { used for spraying? }\end{array}$ & 21 & 17.5 & 99 & 82.5 \\
\hline 9. & $\begin{array}{l}\text { Do you aware of swath width in the calibration of } \\
\text { sprayer? }\end{array}$ & - & - & 120 & 100 \\
\hline 10. & $\begin{array}{l}\text { Spray fluid requirement for low volume } \\
\text { sprayer? }\end{array}$ & 20 & 16.66 & 100 & 83.33 \\
\hline \multicolumn{6}{|c|}{ Precautions and safety measures } \\
\hline 11. & Are you aware of the instructions in the pesticide container? & 96 & 80 & 24 & 20 \\
\hline \multicolumn{6}{|c|}{ During spraying } \\
\hline 12. & $\begin{array}{l}\text { Are you aware of the protective gears that are to be followed during the } \\
\text { spraying? }\end{array}$ & 107 & 89.20 & 13 & 10.80 \\
\hline 13. & Do you consider wind direction while spraying? & 120 & 100 & - & - \\
\hline 14. & $\begin{array}{l}\text { Do you eat, drink or smoke while spraying } \\
\text { pesticide? }\end{array}$ & 120 & 100 & - & - \\
\hline \multicolumn{6}{|c|}{ After spraying } \\
\hline 15. & Do you take bath right after spraying? & 106 & 88.33 & 14 & 11.66 \\
\hline 16. & Do you change clothes after spraying? & 97 & 80.83 & 23 & 19.16 \\
\hline 17. & $\begin{array}{l}\text { Do you wash the bottle/sprayer in the river } \\
\text { /pond / canal /others after spraying? }\end{array}$ & 120 & 100 & - & - \\
\hline 18. & Do you mark any flag to mark your pesticide sprayed plot? & - & - & 120 & 100 \\
\hline 19. & $\begin{array}{l}\text { Are you aware of storing the pesticides at higher level that are not } \\
\text { reachable to children? }\end{array}$ & 109 & 90.80 & 11 & 9.20 \\
\hline \multicolumn{6}{|c|}{ Care and maintenance of equipment } \\
\hline 20. & $\begin{array}{l}\text { Do you disconnect lance, nozzle, discharge } \\
\text { lines from the equipment when not in use ? }\end{array}$ & - & - & 120 & 100 \\
\hline
\end{tabular}

From the table 4 it could be also opined that, there was a vast majority of 96 per cent of the respondents were aware about the instructions that are printed in the pesticide containers but they seek others (fellow farmers, sons and daughters who know English) help to read it since it was not printed in the vernacular language and they rarely adopts the instructions as given in the containers. 
Scientific handling of the pesticides involves protective gears like masks, gloves boots etc., to be worn while spraying the pesticide. There was a overwhelming majority of the respondents $(89.20 \%)$ were aware about the protective gears to be put on while spraying but the adoption is very low. It is discussed in the table.

Consideration of wind also plays a major role in the pesticide spraying, more the wind lesser the effective spray. It leads to drifting of most of spray liquid into the atmosphere. It is evident from the table that 100 per cent of the respondents considers the wind direction while spraying the pesticides. The applicators (100 per cent) don't eat or smoke while spraying the pesticides.

88.33 of the respondents took bath after spraying and nearly 80.83 i.e., more than two third of the respondents of the applicators change their clothes after spraying while only a few 11.66 and 19.16 of the total respondents have not done the both. It is seen that even some of them have separate clothes for spraying purpose.

Cent per cent of the respondents were not washing the empty pesticide container in the rivers or canals or any near by water bodies. It indicated that respondents are well aware about the environmental consequences that is caused by pesticides even after emptying it. After spraying the pesticide in the field it is essential to mark the flag to show that the field is pesticide sprayed to others or strangers. It is found that Cent per cent of the respondents were not marking any type of flag or signal in the field.

In conclusion the most of the farmers in the study area had a medium level of awareness (70.8\%) about the plant health engineering practices. But the farmers are not well aware about the pesticide risks and they require a good education by knowing the evil effect of it. Personal protective equipments should be executed well in the field. Therefore it is strongly recommended to initiate special awareness programs about the pesticide application through KVKs, NGOs and Agriculture departments.

\section{References}

Nigam, G.L and K.S. Murthy, (2000). An optimum use of pesticides in integrated pest management technology, Pesticides Information, 25(1): 6-9.

Jeyanthi, H and S. Kombairaju (2005). Pesticide use in vegetable crops: Frequency, Intensity and Determinant factors. Agricultural economics research review.18:209-221.

Sunil kumar G.M., 2004. A study on farmers knowledge and adoption of production and post harvest technology in tomato crop of Belgaum district in Karnataka. M.sc. (Agri.) Thesis, Univ. Agric.sci., Dharwad.

http://www.fao.org/plant-health2020/about/en/

https://niphm.gov.in/phe.html

\section{How to cite this article:}

Rajapandi, P., L. Nirmala and Mahandra Kumar, K. 2020. Awareness Level of Plant Health Engineering Practices among Vegetable Growers. Int.J.Curr.Microbiol.App.Sci. 9(11): 14221427. doi: https://doi.org/10.20546/ijcmas.2020.911.167 